\title{
From Webcams to Wikipedia
}

\section{There Is An Art \& Feminism Online Social Movement Happening and It Is Not Going Away}

\author{
Angela Washko
}

\section{Bio}

Angela Washko is an artist, writer and facilitator creating new forums for discussions of feminism in spaces especially hostile toward it. In 2012, Washko founded The Council on Gender Sensitivity and Behavioral Awareness in World of Warcraft as an ongoing intervention inside the popular MMORPG. A recipient of The Frank-Ratchye Fund for Art at the Frontier Grant, a Franklin Furnace Performance Fund Grant, a Creative Time Report commission, a Rhizome Internet Art Microgrant, and a Danish International Visiting Artist Grant, Washko's practice has been highlighted in Art in America, Frieze Magazine, Time Magazine, The Guardian, ArtForum, VICE, Hyperallergic, Rhizome, the New York Times, The Creator's Project and more. Her projects have been presented at venues including Kiasma Museum of Contemporary Art, Los Angeles Museum of Contemporary Art, Moving Image Art Fair and the Rotterdam International Film Festival. She is currently a Visiting Assistant Professor at Carnegie Mellon University.

\section{Introduction}

The internet has always been a boys club. Women who choose to delve deeper into the net than their email inboxes needn't look very far to find themselves bombarded by the proliferation of archaic negative gender-based stereotypes in almost every digital space, including online games, meme culture, forums, online journalism, YouTube, and beyond. Every major platform and communication model online appears to be a megaphone for men to remind women that women don't belong or that they are only allowed to participate if they accept their role as objects of admiration or quiet, non-opinionated users, in the event they aren't deemed attractive enough for the former role. It is not uncommon for women online to be stalked, to receive death threats, and to be doxxed. And it is implicitly accepted that women will be under constant scrutiny in most digital spaces, especially if they dare to question these pervasive misogynistic field conditions. These threats can be alarming even when exclusively digital, as women have been raped in online spaces as early as 1993 (Dibbell, 1993).

Fortunately the tides are turning. More and more female cultural producers are forming solidarity networks online, carving out safe spaces for their voices and work. When traditional models of presentationoutside the screen-exclude them, these women have found methods for distributing their work online and producing pieces that explicitly respond to and resist the oppressive climate therein. Self organized all-fe-

angela.washko@gmail.com 
male networks like the following have emerged: publishing projects The Illuminati Girl Gang and Girls Get Busy; all-female social media-based discussion groups and email listservs like FACES and [secret girl group] on Facebook; academia-based feminist online art and technology education networks like FemTechNet; women's indie game making and programming collectives like Dames Making Games and Black Girls Code; feminist online apps and participatory websites like Hollaback!, The Everyday Sexism Project and Stop Street Harassment; feminist podcasts and tumblrs like Women As Objects; as well as individual artists, critics, curators, writers, academics, and supporting institutions. These are all a part of what I would like to consider a new social movement advocating the shift of acceptable behavior on the internet toward greater inclusivity for women.

These collectives, artists, activists, performers, app developers, and game makers are not coming into visibility on their own. These are not isolated incidents, but rather a result of the supportive networks they've created. We are in the midst of an internetbased feminist movement (or, as Dazed and Confused Magazine Digital recently pronounced it, a "digi feminist movement") (Kretowicz, 2014).

To make the case for this as a social movement, I'd like to immediately outline how to define and analyze the movement as well as the scale for determining success and failure. Because of the widely distributed political power structure in America and internet users' resistance to policing internet use (despite the fact that net neutrality no longer exists and we now know that the NSA spies on just about all of our internet behavior) it is hard to track who maintains the power to change the gendered climate of the internet (Wu, 2014). With no visible center to target and goals that are not clearly state-oriented, the political process model endorsed by Doug McAdam is not very helpful for an analysis of this movement (McAdam, 1999). According to Alberto Melucci: "We know that contemporary 'movements' increasingly address cultural issues and tend to differentiate themselves from the model of political action" (Melucci, 1996, p. 78). Some elements from McAdam's book, Political Process and the Development of Black Insurgency 1930-1970 certainly do apply, including the fact that most leaders that emerge in this online feminist movement have already been leaders in their own micro communities; the importance of communication networks to propel the movement; and the "cognitive liberation" that this movement's participants experience. "Cognitive liberation" is Melucci's term to describe an awakening of an individual's awareness of the issues surrounding a movement (in this case, a realization that the internet is not a safe space) and a reframing of the world through that issue (causing one to think "there are bigger reasons why I feel the way I do when I use the net than just one mean comment"). This leads to the realization that one is not alone, inspiring a collective demand for change, hope and action (Melucci, 1996). The breadth of participants recruited to this movement, which I will mention in this essay, are a means of measuring the mass recongition of the systemic issues responsible for maintaing status quo oppression of women online. It can also be measured by the emergence of intense backlash movements such as the counterfeminist groups on reddit, 4chan, and antifeminist movements like Men's Rights Activists or MRAs (Blais, 2012). These factors indicate that there is an online feminist movement taking place including artists, writers, coders, educators, game developers and more working across disciplines to shift attitudes towards women on the web.

To effectively analyze this contemporary internet feminist movement, we have to look at its solidarity, its goals, its demands, and its mobilization. I am asking that we allow the demands (most generally: a more inclusive internet for women) to be examined within the realm of the internet, leaving aside for a moment the scope and impact of the movement beyond the screen. There are many documented cases of feminist online activism employed to make changes in physical public space (Plank, 2014), but I am asking that we allow this movement to be analyzed for its impact and functionality within digital spaces.

Alberto Melluci's criteria for a social movement, outlined in his book Challenging Codes, is helpful in defining this feminist art and net activism cross-over community as a social movement. By his standards, a social movement must be defined by "specific solidarity among members," must be "engaged in a conflict with an adversary over control and use of resources valued by both parties," and must have experienced "a breach in the limits" of the hegemonic system in which the collective action takes place (Melluci, 1996, p.28). One might argue 
that these cultural producers are actually participating in "individual mobility." However the nature of social media and other internet communication networks turn these seemingly aggregate behaviors into a streaming collective narrative. The rapid, incessant flood of stories of women responding to unchecked male net aggression melds into one distinct tale of unjust internet sexism. In light of shortened attention spans, information overload and constant connectivity, the creation of narrative is important to these net feminists largely in order to distribute and sum up the repeated stories of misogynistic transgression. Their impact binds together individuals who strongly identify with the movement and its other participants (solidarity). This is consistent with literary critic J. Hillis Miller's observation about stories and social movements, as described by Francesca Poletta: "The impossibility of logically explaining events compels us to tell stories...we always need more stories because in some way they do not satisfy" (Poletta, 2006, p. 43).

Whether or not these stories are compelling, participants' identification with the movement does not occur instantly, as Alberto Melluci observes:

"Constructing a collective identity entails continuous investment and unfolds as a process: identity crystallizes into forms of organization, systems of rules and leadership relationships the closer the action draws toward the more institutionalized forms of social behavior" (Melluci, 1996).

Unlike physically-observable protest movements, which manifest in picket lines, civil disobedience, organizational infrastructure with recruitment campaigns, and political petitioning, it is harder to trace this as a social movement, because the formation of collective identity is largely based on its deeply intertwined digitally-networked existence. In my experience, once you are initiated into or seek out the movement, you are instantly linked to hundreds of others working in the same arenas. Even more difficult to trace as an outsider, the group's activities and recruitment of membership occurs on a global and local scale. As enthusiasm regarding like-minded feminist online projects circulate through one's curated social network, one becomes connected to others with similar working methodologies around the world. Triple Canopy writes in their text Pointing Machines: "This is what it's like when distance collapses. Everything is near, and nothing that is not can be perceived" (Triple Canopy, 2014). In order to analyze the movement further, we must understand that members of this movement are on a battleground shrouded with anonymity (though this is shifting). The infrastructure of the internet lacks accountability and a physical location to air grievances. We must consider both formal and informal umbrella organizations founded online to be institutions; we must allow Facebook groups and multi-user Google Docs to be town halls; we must allow critical journalism responsive to these issues and collectively-produced feminist online zines, independent video games, tumblrs and their subscribers and subsequent comment sections to be protest movements without a physical manifestation.

As stated earlier, there are risks to participating in this movement. How is anyone recruited to a cause that will likely result in harassment, even in daily life outside of digital space (Lewis, 2012; Reinsberg, 2012; Roy, 2012; Sarkeesian, 2012; Hess, 2014)? The movement's recruiting has a lot of the same appeal that Kathleen M. Blee describes in her book Inside Organized Racism: Women in the Hate Movement, a case study of women in and how they are recruited to predominantly male racist movements (though clearly these movements have vastly different political and social aims). The online feminist movement helps women comprehend why their online experiences are often so saturated with gender discrimination. It frames these behaviors as systemic, giving these women something to unite around and react against (Blee, 2012, p. 82). The more these recruits feel the sense of a polarized $u s$ (women or feminists or victims) vs. them (misogynists or MRAs or trolls or attackers etc) dynamic, the more likely collective identity will lead to collective action, reducing ambivalence toward the conditions and ultimately propelling action (Melluci, 1996, p. 83).

It is undeniable that new social movements use social media to mobilize action. Segerberg and Bennet, Theocharis et al., Castells, Gitlin, and many other scholars have theorized the utility and effectiveness of social media. But what about a movement that is already online? All action in this online feminist movement is coordinated through social media, email, and browsers. These movements' networks are formed almost entirely online. There are physical hubs that pop up, but they do so largely after solidar- 
ity is established online. Several physical manifestations of the movement-including all-women text compilations, female-only performance events and exhibitions, as well as conferences and "meatspace" gatherings in major cities-have all occurred, but only in response to internet organizing activity (Alvarez, 2013; Eler, 2013; Kirsch, 2013). If these physical manifestations of online practices have impact on the movement, they might take the form of building awareness in other publics, potential funders and like-minded organizations. They may also increase solidarity within the existing group and bring offline "legitimacy" to the online movement.

Tactically, the movement takes physical protest strategies and translates them in a digital realm. Social media replaces both traditional meetings and protests. Actions are coordinated on Facebook groups and events. Journalists participate in these groups and publish articles on news blogs. Ultimately, increased press coverage results. The now yearly Art+Feminism Wikipedia Edit-a-thon event is a notable example of this process in action (Hallett 2014; Howard 2014; Stoeffel, 2014). How did one Facebook event become a massive $85+$ institution action? The achievements of this event were made possible through the incredible coordination, extensive networks, and solidarity of this online feminist movement (deemed Art+Feminism in this particular event's case). Initially organized by Sian Evans, Jacqueline Mabey, Laurel Ptak, and Michael Mandiberg, with institutional support from Eyebeam Art and Techology Center and the Art Libraries Society of North America's Women and Art Special Interest Group, the impulse to edit Wikipedia-creating an online art history that represents women-spread to other networks like wildfire (Cemblest, 2014). Universities, libraries and art spaces hosted events to encourage informed participation in this digital action. Less than $13 \%$ of Wikipedia editors and contributors are women (Cohen, 2011). Thus, even in a knowledge database open to public contribution, women feel threatened to participate (Cohen, 2011). In the first iteration of this highly organized action, 101 women artists were added to Wikipedia and over 80 more entries on women were expanded, adding not only more worthy historical female subjects to Wikipedia's account of history but also training more women to be approved contributors (Cohen, 2011). The calls to participate and satellite locations were all coordinated and distributed through social media, a Wikipedia Meetup page, email listservs, and online press (my invitation to participate in the original New York City event at Eyebeam came through Facebook). The event was clearly a concentrated action aimed at correcting the biases inherent in the exceptionally male skewed resource self-identifying as "the free encyclopedia that anyone can edit (Wikipedia, 2014)." The overwhelming mass participation evidenced the growing power of the online feminist (art) movement. Additionally, the, rapid planning, spread and execution of the Art+Feminism Wikipedia Edit-a-thon made for great storytelling, and instantly facilitated the planning of another event that occurred a month later. The language used to describe the event on the Art+Feminism Wikipedia Edit-a-thon's own Wikipedia page uses terminology like "viral," "sprint," "immediate," and "came together in a matter of minutes," giving the appearance of spontaneity. The language to describe the accumulation of participants, the spread of this direct action and the rapid formation of solidarity is consistent with Polleta's analysis of storytelling in civil rights and anti war movements; expressing the immediacy and spontaneity of direct action communicates that action as "expressive and powerfully moral" (Poletta, 2006).

Many members of the online feminist movement are storytellers whose tales contribute to the stream of proactive unrest backing actions like the feminist Wikipedia swarm edit. The internet itself has become a place for women to carve out autonomous spaces for themselves that aren't available to them in the material public sphere. Aside from the publishing niches for women I've already mentioned, many of the artists and writers participating in this movement create highly diaristic work that responds to genderrelated injustices and trauma they've experienced (now through a feminist lens, recognizing these injustices as a product of institutionalized patriarchy). These artists rapidly produce selfies and video blogs online as a way to create visibility and take back control over representation of their identities and experiences (Hirsch, 2011; Patterson, 2013). The public's voyeuristic investment and simultaneous discrediting of these broadcast chronicles of (typically young) women reveal further evidence of the gendered climate of the internet. Other critics attempt to capitalize on, undermine, and demand changes from the women who participate in these practices (Berlatsky, 2011). The persistence of these selfies and 
unabashedly women-centric tumblrs, despite public demonization of the so-called narcissistic young-girl, confirms that these spaces carved out for women and by women are going to stay (and only get bigger).

On their own, these selfie tumblrs do not constitute a social movement. It is the mass culmination of these impulses-combined with critical writing, artistic work, networking, building of safe spaces, interventions on exclusionary net spaces, and ultimately the cognitive liberation of members of the group identifying themselves with the movement-that change the internet's climate. An increasing number of larger institutions recognize the efforts of these online feminists and the existence of a movement, providing support for them in a variety of ways. According to their website, FemTechNet is a cross-university "activated network of scholars, artists and students who work on, with, and at the border of technology, science and feminism" (Juhasz \& Balsamo, 2012). Through networked education programs, FemTechNet both teaches a new generation of students tools and approaches to participating in digital feminist activism and also connects feminists "across the globe," producing an academia-oriented "master frame" that asserts online feminist activism as necessary to combat dominant, exclusive, normative male dominion over the net (Snow, 2007). FemTechNet supports many micro online feminist activist groups and individual actors, providing a clearer narrative context and umbrella network consistent with Snow's description of master frames (Snow, 2007). DIY, organized "secret girl groups" on social media illustrate the personalization of politics outlined by Bennet in "The Personalization of Politics: Political Identity, Social Media, and Changing Patterns of Participation" (Howard, 2014). The participants of these groups are committed to making expressive personal works (art, writing etc.), but function collectively as more than a support group or safe space. The secret girl group I participate in fundraises for grants for women artists, creates exhibitions comprised of exclusively women, and creates informal direct action (often agitating against individuals and institutions that support all-male exhibitions online and in physical space). It also creates working documents that outline female cultural producers with digifeminist interests and recruits other women who demonstrate individual activity in this realm.
People are quick to dismiss online activities as "slacktivism" (the idea that people working in social activism online are only clicking links and sharing articles amongst each other and not "actually doing anything"). Yet a lot of the actions propelled by participants in this movement are highly coordinated and technologically impressive. Another organization contributing to the ethos of the movement is Hollaback!, an online and offline non-profit with a mission to end street harassment. Their online website and phone app is a space to share street harassment experiences (in 71 cities and 24 countries) with women who've had similarly threatening encounters (Bates, 2013). Although sexist street harrassment is not an online issue (though the tactics and approaches do appear similar to harassment of women online), the internet becomes a haven for sharing these stories, fostering greater solidarity among online feminists and inspiring other networked actions and a culture of "saying something" rather than ignoring these issues (Blais \& Dupuis-Deir, 2012; Macaskill \& Dance, 2013).

While the mentioned artists, tumblr curators, writers, educators and organizations are operating individually, the proliferation of their contributions to the web make it obvious that they are conscious of the movement and have some solidarity with it, whether explicitly described or not. The disparate power relationships between men and women in digital spaces has been so pervasive an issue in artists' lives that they devote focused bodies of work to these problems. Additionally, the nature of the globally networked art world renders artists acutely aware of and connected to similar working artists, increasing the chances that personal struggle will be recognized as collective struggle. Jennifer Chan makes videos and web-based work from a feminist perspective, often responding to masculine tropes and gendered expectations online. In addition to artworks, she contributes to these issues through her writing and organizing of feminist events (including a Chicago satellite event of the previously mentioned Art+Feminism Wikipedia Edit-a-thon), evidence of a keen awareness of and commitment to this feminist online social movement (Chan, 2011). Members of earlier cyberfeminist collectives like VNS Matrix and Old Boys Network engaged these issues not only with their individual art practices but also by organizing events and producing critical writing. These were essential to paving the way for web 2.0 feminist artist/organ- 
izer/writers like Addie Wagenknect, Evelin Stermitz, Ann Hirsch, Gabby Bess, Laurel Ptak, and Caroline Woolard, just to name a few.

How can we measure success or failure in this social movement (assuming at this point we agree that it is a social movement)? Anita Sarkeesian's Kickstarter fundraising campaign for her educational online video series, which deconstructs the reinforcement of negative female stereotypes in video games, is a captivating case study. Sarkeesian turned to crowd-funding platform Kickstarter to raise $\$ 6000$ to produce a series of web videos called Tropes vs. Women in Video Games (Watercutter, 2012). As a result of this project, the climate of online gaming communities and her outspoken feminist position, Sarkeesian became the subject of extremely brutal harassment (including the creation of a series of games made by her "critics," in which players beat her face until it turns black, blue and bloody, as well as hundreds of image macro memes designed to discredit, insult, or humiliate her) (Lewis, 2012). Ultimately, her supporters were moved by both the critical feminist content she proposed and the obscene amount of harassment and visible threats of violence she endured, as her Kickstarter campaign far exceeded the amount requested. Tropes vs. Women in Video Games earned \$158,922 in crowd-funded donations from 6,968 donors. That's 26.487 times more than Anita Sarkeesian asked forquite the backlash to online sexism.

Writers like Leigh Alexander, who advocates for greater inclusivity for women in video games, are earning high-ranking positions in major news publications in their fields (including Gamasutra, Kotaku and Offworld in Alexander's case) (Isaacson, 2013). In their positions, they are afforded an authoritative and far-reaching voice to recruit and empower other women. The fact that Alexander and other movement participants are being placed in positions of power is evidence that the system is changing and that the movement is having at least some success in bringing these issues into public dialogue and putting its participants into positions to make changes in a myriad of public institutions outside of the screen: museums, written publications, universities, non-profits, and more. There is still no shortage of hostility toward these public figures' feminist platforms (for instance, a forum topic on Leigh Alexander's writing is titled "Leigh Alexander being a dumb bitchy cunt" [Korgan, 2011]), but the support for wider online distribution and visibility of gendersensitive, critical indie games and more diverse game makers like Anna Anthropy (whose book Rise of the Videogame Zinesters: How Freaks, Normals, Amateurs, Artists, Dreamers, Drop-outs, Queers, Housewives, and People Like You Are Taking Back an Art Form is also an indication of the kind of maker-led activism I've described earlier) make it clear that these online feminist cultural producers are winning. "At any rate, [misogynist gamers are] losing," writes Leigh Alexander. "They had the delusion of grandeur gleaned from the past decade's economic growth, but the commercial games business is shrinking again, because everyone but these people are now grownups who aren't still obsessed with how they were picked on in high school. Games will absolutely have to reject their hostile little niche and appeal to more people if they want to be financially viable. The core gamer just isn't relevant anymore, which is probably why he's pitching such a fit." (quoted in Brin, 2013).

Why would we look at all of these seemingly disparate modes of production as part of the same movement? Despite the technical, formal, and contentoriented differences between the online writing, art, activism, game-making and formats outlined above, these practices are, fundamentally, producing the same discussions around bringing visibility to issues facing women. They call for inclusivity and the creation of safe spaces for women in these volatile contexts. Culture Hub went so far as to call 2014 "The Year of Digi Feminism (Kretowicz, 2014)." Essays are coming out left and right about "the art world's feminism" and magazines, blogs, online TV stations, and journals are springing up all over the place wholly devoted to discussing feminist issues online (Kirsch, 2014). Looking at this movement from the perspective of Armstrong and Bernstein's "Multi-Institutional Politics Approach to Social Movements," we should move beyond the idea that power is controlled exclusively by the state and recognize that there are many institutions and systems at play that reinforce existing meaning systems. This makes the prospect of changing the prevailing sexist environment an incredibly difficult task, as it is economically, politically and socially designed to remain the same (Armstrong \& Bernstein, 2008). Members and organizers involved in this digi feminist movement recognize and respond to these challenges by taking on a multi-faceted approach: targeting diverse fields from journalism to YouTube to poetry to sex work 
to phone apps to Facebook to the university to video games to museums to trade networks to conferences to tumblr and beyond. Influenced by the issues raised by 1990 s cyberfeminism, the energy and reach of the Riot Grrrls, and the tactics of the Guerrilla Girls, these women recruit more to their ranks. There will be a revolution and it will be online.

\section{References}

Alvarez, AC (2013, September 22). The Artists of gURLS. The Daily Beast. Retrieved from http:// www.thedailybeast.com/witw/articles/2013/09/22/ feminist-online-art-and-the-women-of-gurls.html

Armstrong, E \& Bernstein, M (2008). Culture, Power, and Institutions: A Multi-Institutional Politics approach to Social Movements. Sociological Theory.

American Sociological Association. March 2008 ed., 74-99.

ArtFem.TV. Art and Feminism TV. Retrieved from http://artfem.tv

Avedisian, A (2015, May 6). Subverting Mass Media: The Collection of the Girls of the Internet Museum Accentuates Sincerity. Art 21 Magazine. Retrieved from http://blog.art21.org/2015/05/06/subverting-mass-media-the-collection-of-the-girls-ofthe-internet-museum-accentuates-sincerity/

Bates, L (2013, April 16). The Everday Sexism Project: A Year of Shouting Back. The Guardian. Retrieved from http://www.theguardian.com/lifeandstyle/the-womens-blog-with-jane-martinson/2013/ apr/16/everyday-sexism-project-shouting-back

Bates, L (2013, May 30). The day the Everyday Sexism Project won - and Facebook changed its image. The Independent. Retrieved from http://www.independent.co.uk/voices/comment/the-day-the-everyday-sexism-project-won-and-facebook-changed-itsimage-8636661.html

Berlatsky, N (2013, November 22). Selfies Are Art. The Atlantic. Retrieved from http://www.theatlantic.com/entertainment/archive/2013/11/selfies-are$\operatorname{art} / 281772 /$

Blais, M \& Dupuis-Deri, F (2012). Masculinism and the Antifeminist Countermovement. Social Move- ment Studies: Journal of Social, Cultural and Political Protest. 1 (1), 21-39.

Blee, KM (2002). Inside Organized Racism: Women in the Hate Movement, Berkeley and Los Angeles, CA: University of California Press.

Bluestockings Magazine. Retrieved from: http://bluestockingsmag.com/

Brin, S (2013, May 10). Feminism and Videogames: A Look at Anita Sarkeesian's 'Tropes vs. Women' Series. The Creator's Project. Retrieved from http:// thecreatorsproject.vice.com/blog/feminism-and-videogames-a-look-at-anita-sarkeesians-tropes-vs-women-series

Bystrom, Arvida. Arvida BystromTumblr. Retrieved from http://arvidabystrom.tumblr.com/

Cembalest, R (2014, February 06). 101 Women Artists Who Got Wikipedia Pages This Week. ARTnews. Retrieved from http:/www.artnews.com/2014/02/06/ art-and-feminism-wikipedia-editathon-creates-pagesfor-women-artists/>

Chan, J (2011, June 04). Why Are There No Great Women Net Artists? Pool Journal. Retrieved from http://pooool.info/why-are-there-no-great-womennet-artists-2/

Chan, J (2013). Community Without Community: Net Art and its Micro-spheres.West Space Journal. Issue 1. Retrieved from http://westspacejournal.org. au/article/winter-2013/community-without-community-net-art-and-its-micro-spheres/

Cohen, N (2011, January 30). Define Gender Gap? Look Up Wikipedia's Contributor List. New York Times. Retrieved from http://www.nytimes. com/2011/01/31/business/media/31link.html? $\mathrm{r}=2$ \&hpwDefine\&

Culture Hub. In Facebook [Fan page]. Retrieved January 27, 2014 from https://www.facebook.com/CultureHubNYC/posts/10200906667103511?stream ref $=10$

Darling, J, Kirton, R \& Soda, M (2013, April). Girl Swarm and The Soda Stream. Cluster Mag. Re- 
trieved from http://theclustermag.com/2013/04/girlswarm-and-the-soda-stream/

Dibbell, J (1993, December). A Rape in Cyberspace. The Village Voice. Retrieved from: http://www.villagevoice.com/2005-10-18/specials/a-rape-in-cyberspace/

Dox [Encyclopedia Entry]. Retrieved March 1, 2014 from Urban Dictionary: http://www.urbandictionary. com/define.php?term=doxed

dpi Journal of Feminist Art and Digital Culture. Retrieved from http://dpi.studioxx.org/en

Durbin, K (2011-2013). Women As Objects [Blog]. Retrieved from http://womenasobjects.tumblr.com/

Eler, A (2013, March 13). Moments of Female Adolescence, Illuminated Online and in Print. $\mathrm{Hy}$ perallergic. Retrieved from http://hyperallergic. com/66869/moments-of-female-adolescence-illuminated-online-and-in-print/

FACES: Gender, Technology, Art [listserv homepage]. Listserv Homepage. (2013). Retrieved February 29, 2014 from http://faces-l.net/

Hallett, A (2014, January 15). Wikipedia Arts + Feminism Edit-A-Thon. The Portland Mercury. Retrieved from http://www.portlandmercury.com/BlogtownPDX/archives/2014/01/15/wikipedia-arts-feminism-edit-a-thon

Hess, A (2014, January 06). Why Women Aren't Welcome on The Internet. Pacific Standard Magazine. Retrieved from http://westspacejournal.org.au/ article/winter-2013/community-without-communitynet-art-and-its-micro-spheres/

Hirsch, A (2011, May 10). bebe zeva and overcoming the hatred of the american teenage girl. Retrieved from http://therealannhirsch.tumblr.com/ post/5365541304/bebe-zeva-and-overcoming-thehatred-of-the

Hirsch, A \& Washko, A (2013). A Cups Episode \#2 - Rachel Rabbit White. A CUPS. Podcast retrieved from https://itunes.apple.com/us/podcast/a-cups/ id664314007? $\mathrm{mt}=2$
Howard, D (2014, February 05). Wikipedia Meets Feminism. The Daily Beast. Retrieved from http:// www.thedailybeast.com/witw/articles/2014/02/05/ wikipedia-meets-feminism.html

Isaacson, B (2013, October 11). Leigh Alexander On The Biggest Problem With Video Games Today. The Huffington Post. Retrieved from http://www.huffingtonpost.com/2013/10/11/leigh-alexander-videogames_n_4032080.html

Juhasz, A \& Balsamo, A (2012). An Idea Whose Time Is Here: FemTechNet - A Distributed Online Collaborative Course (DOCC). Ada Journal of Gender, New Media \& Technology. 1. Retrieved from http://adanewmedia.org/2012/11/issue1-juhasz

King-Slutzky, J (2013, August 13). What It's Like to Be Tumblr Famous. Motherboard. Retrieved from http://motherboard.vice.com/blog/what-its-like-tobe-tumblr-famous

Kirsch, C (2013, October 04). The Digital Art World's (Secret) Feminism. Art F City. Retrieved from http://artfcity.com/2013/10/04/the-digital-artworlds-secret-feminism/

Kirton, RG [Blog]. Retrieved from http://grossmary. tumblr.com/tagged/gpoy

Know Your Meme (2010). Get Back To The Kitchen. Retrieved February 29, 2014 from http://knowyourmeme.com/memes/get-back-to-the-kitchen

Know Your Meme (2011). Make Me A Sandwich. Retrieved February 29, 2014 from http://knowyourmeme.com/memes/make-me-a-sandwich

Know Your Meme (2011). 2/10 Would Not Bang. Retrieved February 29, 2014 from http://knowyourmeme.com/memes/210-would-not-bang

Korgan (2011, August 14). Leigh Alexander being a dumb bitch cunt [Msg 1]. Message posted to http:// www.rpgcodex.net/forums/index.php?threads/leighalexander-being-a-dumb-bitchy-cunt.63066/

Kretowicz, S (2014, February). Our ten favourite digifeminist artists. Dazed and Confused Digital. Retrieved from http://www.dazeddigital.com/artsand- 
culture/article/18432/1/our-ten-favourite-digifeminist-artists>

Lewis, H (2012. July 06). This is what online harassment looks like. New Statesman. Retrieved from http://www.newstatesman.com/blogs/internet/2012/07/what-online-harassment-looks

Macaskill, E \& Dance, G (2013, November 1). The NSA Files, Decoded. The Guardian. Retrieved from http://www.theguardian.com/world/interactive/2013/ nov/01/snowden-nsa-files-surveillance-revelationsdecoded\#section/1

McAdam, D (1999). Political Process and the Development of Black Insurgency 1930-1970 (2nd ed.). Chicago, IL: The University of Chicago Press.

Meadham, E (2012). Zine Watch: Girls Get Busy. Dazed and Confused Magazine. Retrieved from http://www.dazeddigital.com/artsandculture/article/14249/1/zine-watch-girls-get-busy

Meetup/ArtAndFeminism/FAQ. (n.d.). Retrieved February 29, 2014 from Wikipedia:http:// en.wikipedia.org/wiki/Wikipedia:Meetup/ArtAndFeminism/FAQ

Melluci, A (1996). Challenging Codes. Cambridge, UK: Press Syndicate of the University of Cambridge.

Naili, H (2013, August 15). Feminists Launch Model for Online Learning. Women's E-News. Retrieved from http://womensenews.org/story/education/130814/feminists-launch-model-online-learning\#.Uylg_IX6_eI

Narcisse, E (2011, November 08). One Female Gamer Records A Warfare in Words. Kotaku. Retrieved from http://kotaku.com/5857333/one-female-gamerrecords-a-warfare-in-words

O'Meara S (2012, July 06). Internet Trolls Up Their Harassment Game With 'Beat Up Anita Sarkeesian. The Huffington Post UK. Retrieved from http://www. huffingtonpost.co.uk/2012/07/06/internet-trolls-online-beat-up-anita-sarkeesian-game_n_1653473.html

Patterson, M (2013, April 25). Girls Make Games Too: A Chat with Dames Making Games. Toronto Standard. Retrieved from http://www.torontostand- ard.com/industry/girls-make-games-too-a-chat-withdames-making-games/

Plank, E (2014, February 17). 23 Inspring Feminist Digital Campaigns That Changed the World. Policy Mic. Retrieved from http://www.policymic.com/ articles/80229/23-inspiring-feminist-digital-campaigns-that-changed-the-world

Polletta, F (2006). Like A Fever: Storytelling in Protest and Politics. Chicago, IL: University of Chicago Press.

Reddit. MensRights. Retrieved February 25, 2014 from http://www.reddit.com/r/MensRights/

Reinsberg, H (2012, July 18). 4Chan Hacks Feminism.org to Make Rape Jokes. Buzzfeed. Retrieved from http://www.buzzfeed.com/ hillaryreinsberg/4chan-hacks-feminismorg-to-makerape-jokes

Roy, J (2012, September 10). What Happens When You Taunt 4chan: The Story of Lacey Vicich. BetaBeat. Retrieved from http://betabeat.com/2012/09/ what-happens-when-you-taunt-4chan-the-story-oflacey-vicich/

Sarkeesian, A (2012, July 01). Image Based Harassment and Visual Misogyny. Feminist Frequen$c y$. Retrieved from http://www.feministfrequency. com/2012/07/image-based-harassment-and-visualmisogyny/

Sharkey, J (2013, October 21). A Worldwide Fight Against Street Harassment. The New York Times. Retrieved from http://www.nytimes.com/2013/10/22/ business/fighting-harassment-of-women-on-streetsworldwide.html?_r=0

Smith, E (2012, October 06). Hey baby! Women speak out against street harassment. $C N N$. Retrieved from http://www.cnn.com/2012/10/06/living/streetharassment/

Snow, DA (2007). Framing Processes, Ideology, and Discursive Fields. In D. A. Snow \& S. A. Soule \& H. Kriesi (Eds.), Blackwell Companion to Social Movements. (pp. 380-412). Hoboken, New Jersey: WileyBlackwell. 
Stoeffel, K (2014, February 11). Closing Wikipedia's Gender Gap - Reluctantly. NY Magazine. Retrieved from http://nymag.com/thecut/2014/02/closing-wikipedias-gender-gap-reluctantly.html

Triple Canopy (2014, March 07). Pointing Machines. Triple Canopy. Retrieved from http://canopycanopycanopy.com/contents/pointing_machines

Washko, A (2014, November 20). Why Talk Feminism in World of Warcraft?. Creative Time Reports. Retrieved from http://creativetimereports. org/2014/11/20/angela-washko-feminism-world-ofwarcraft-gamergate/

Watercutter, A (2012, June 14). Feminist Take On Games Draws Crude Ridicule, Massive Support. Wired Magazine. Retrieved from http://www.wired. com/2012/06/anita-sarkeesian-feminist-games/
White, RR (2013, September 16). Oh gURL: It's so good to finally meet u IRL. Rhizome. Retrieved from http://rhizome.org/editorial/2013/sep/16/oh-gurl/

Wikipedia (n.d.). Retrieved February 29, 2014 from Wikipedia: https://en.wikipedia.org/wiki/Wikipedia

Wu, T (2003). Network Neutrality, Broadband Discrimination. Journal of Telecommunications and High Technology Law, 2, 141-180.

Wu, T (2014, January 15). Who Killed Net Neutrality?. The New Yorker. Retrieved from http://www. newyorker.com/online/blogs/elements/2014/01/whokilled-net-neutrality.html 